\title{
II. SITE SURVEY, DSDP SITE 386
}

\author{
Frederick A. Bowles, NORDA/NSTL, Naval Oceanographic Laboratory, Sea Floor Division, Bay St. Louis, Mississippi
}

\section{INTRODUCTION}

Detailed geophysical surveys were carried out in the region east-southeast of Bermuda during cruises of USNS Kane (May 1974) and USNS Wilkes (October 1974). DSDP Site $386\left(31^{\circ} 11.2^{\prime} \mathrm{N}, 64^{\circ} 14.9^{\prime} \mathrm{W}\right)$ was selected in part on the basis of these survey operations; the part of the survey near Site 386 is shown in Figure 1. Because of the detailed coverage by both ships, a pre-drilling survey was not conducted.

Continuous underway bathymetric $(3.5 \mathrm{kHz}$ and 12 $\mathrm{kHz}$ ) and seismic reflection profiles were collected along the survey track with satellite and LORAN C navigational control. Bathymetric and isopach (sediment thickness) maps were constructed from the profiles. The bathymetric profiles were digitized at all inflection points. The seismic reflection profiles were obtained with three 30,000 joule "sparker" sound sources fired simultaneously at 10-second intervals. Sediment thickness above acoustic basement in seconds of twoway travel time was read every 15 minutes (a distance of nearly 5 kilometers between readings at a normal survey speed of about 10 knots). Assuming a velocity of $2.0 \mathrm{~km} / \mathrm{sec}$ for the sediments, one second of reflection time represents 1 kilometer of thickness.

\section{GEOLOGIC SETTING}

The Bermuda Rise is an elongate northeast-southwest trending asymmetrical arch $(550 \times 1100 \mathrm{~km})$ near the center of which lies the Bermuda Pedestal and surrounding depositional apron. The pedestal is approximately $95 \times 150 \mathrm{~km}$ at its base; it is flat-topped and capped by the islands of Bermuda (Heezen et al., 1959). Site 386 is located approximately $150 \mathrm{~km}$ southeast of Bermuda near the outer edge of the depositional apron.

Passing near or through Bermuda and trending approximately northeast to north-northeast is the Bermuda Discontinuity (Vogt et al., 1971). The discontinuity marks the young end of the Keathley magnetic lineations and separates generally rugged, densely fractured basement on the east flank of the rise from smoother basement toward the west. Most of the fractures do not cross the discontinuity and remnant midocean ridge topography occurs between the fractures. Also associated with the discontinuity is an increase in mean basement depth to the west.

\section{TOPOGRAPHY}

The original or primary basement relief of the Bermuda Rise can be attributed to sea-floor spreading processes at the crest of the Mid-Atlantic Ridge. Based on roughness patterns, Holcombe and Heezen (1970) have divided the rise into four provinces. The sedimentary apron around Bermuda stands out as a province of sediment-subdued terrain having generally low relief $(20-100 \mathrm{~m})$ and gentle slopes (less than $\left.5^{\circ}\right)$. Most of the rise is categorized as "rough" sea floor where amplitudes of 100 to 400 meters slopes of 5 to $15^{\circ}$, and wavelengths (distance between topographic highs) of 20 to $55 \mathrm{~km}$ predominate.

Site 386 falls within a region of rugged topography just eastward of the depositional apron. A detailed bathymetric map of the area (Figure 2) shows that the region is dominated by a broad topographic high north of the site and a smaller but also prominent high immediately to the south. Greatest relief is observed in the north where outcrops rise several hundred meters above the surrounding sea floor. Total relief in the area is 1004 meters with the shoalest part being 3721 meters and the deepest part about 4725 meters. In general, the intervening sea floor between the highs is topographically uniform and slopes toward the south in the direction of the site. The site itself is located within the 4725 -meter contour near the base of the southern topographic high.

\section{SEISMIC REFLECTION}

Seismic reflection profiles in Figures 3 and 4 illustrate the nature of the subsurface reflecting layers in the area surveyed. In general, the sediments are divided into two distinct stratigraphic sections by a zone of acoustically laminated sediments lying from 0.1 to 0.5 seconds beneath the sea floor (Horizons $A^{V}, A^{T}$, and $A^{C}$, Tucholke, this volume). The complexity of the zone varies somewhat, the reflectors sometimes defining two distinct acoustic intervals (G-P, Figure 4). The well-layered and intensely reflective nature of the zone and the fact that the reflectors terminate abruptly against basement outcrops suggest that the zone consists of tubidite deposits.

The reflective zone caps what appears to be a poorly to moderately stratified interval of sediments overlying basement. In some places an entire complex of reflectors can be traced nearly to basement whereas in other places the sediments appear to be predominantly nonlaminated. Variation in the reflectivily of the layers within this lower sedimentary unit suggests a combination of pelagic and turbidite deposition.

The topmost sedimentary unit (overlying the welllayered, reflective zone) exhibits usually weak internal reflectors. The generally transparent nature of these sediments suggests pelagic deposits. Unlike pelagic deposits, however, the surface topography does not al- 


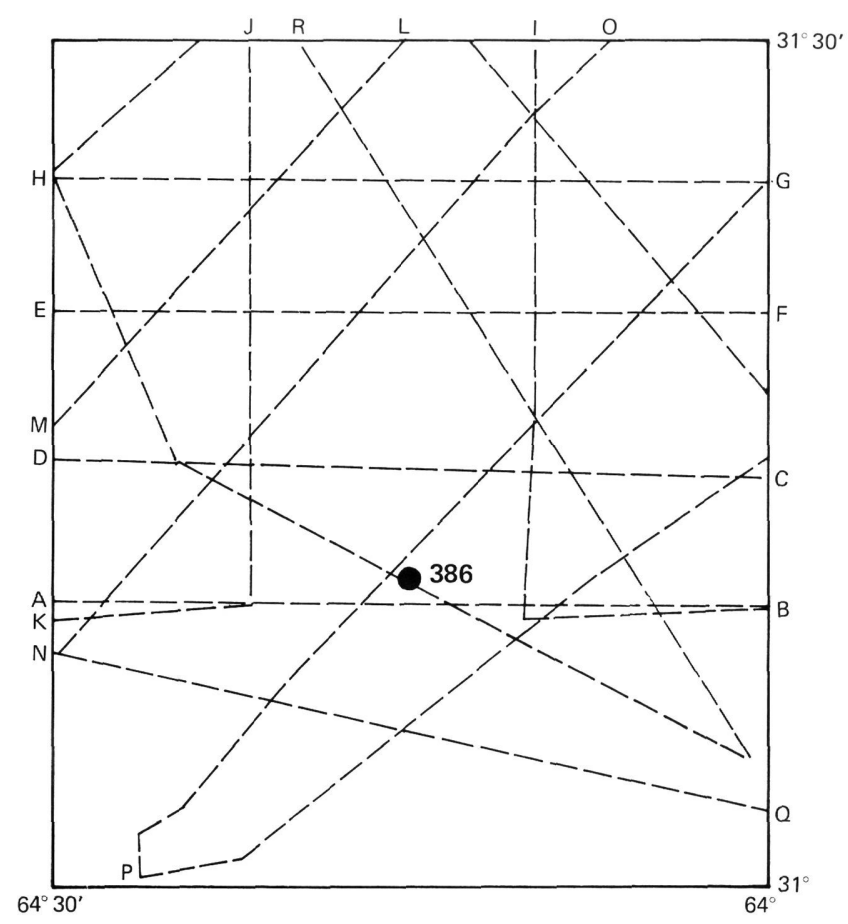

Figure 1. Track chart chowing combined cruises of Kane and USNS Wilkes. Letters apply to indexed seismic reflection profiles.

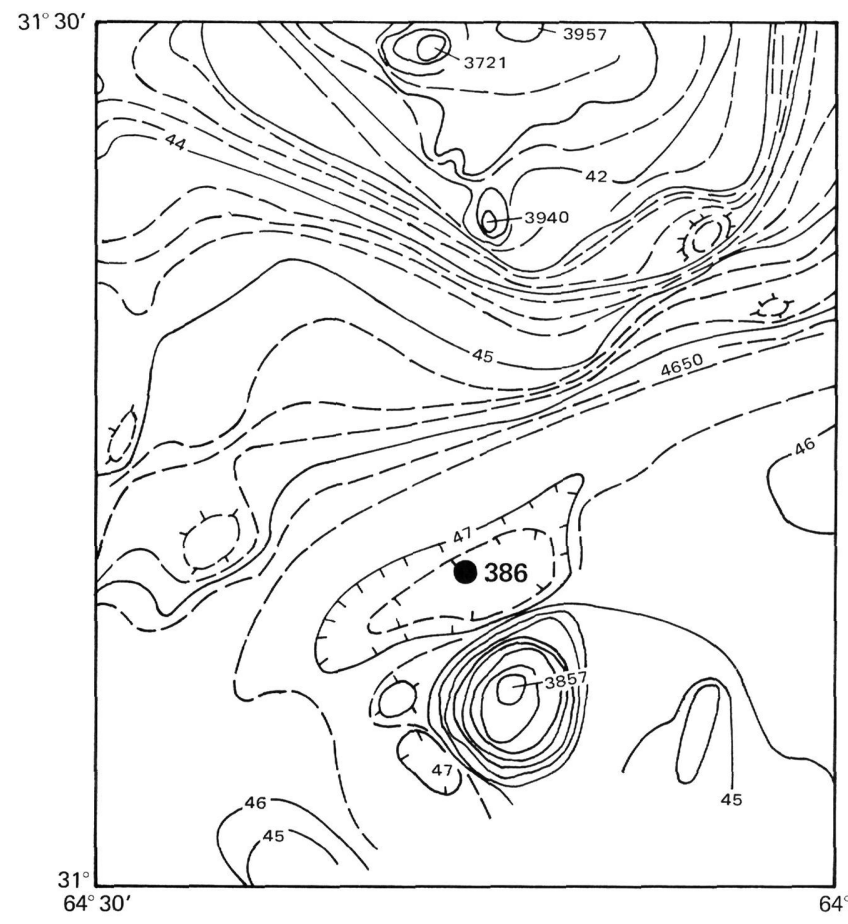

Figure 2. Bathymetric map of DSDP Site 386 contoured in uncorrected meters at 25-meter intervals. Solid circle indicates location of drilling site.

ways seem to conform well to the underlying basement topography. This is due, in part, to the probability that some portion of the sediments below the top sedimentary unit have been deposited by turbidity currents which favor deposition in basement depressions. The pattern of sediment cover in the upper unit, however, also indicates prevalent erosion and redeposition of the sediments by bottom currents. In profiles B-I (Figure 3 ) and N-O (Figure 4), for example, there is considerable difference in sediment thickness on either side of the broad northern topographic high. Such variation can be observed in other profiles and are indicative of current-controlled deposition or local slumping.

\section{SEDIMENT THICKNESS}

The distribution of sediments in the survey area is shown in Figures 5, 6, and 7 as isopach maps of sediment thickness above acoustic basement. Total sediment thickness is shown in Figure 5. The northern portion of the area stands out as a region of thin sediment cover with a few isolated outcrops and is coincident with the broad topographic high shown in Figure 2. Thick sediment fill marks the deep basement depression between the high-standing topography to the north and south of Site 386 .

Isopachs of the lowermost sedimentary unit (below the strong, shallow reflector Horizon $A^{b}$ ) are shown in Figure 6. The contours are similar in pattern to those in Figure 5, and in both cases the nature of the contours (east-west trending, open to the west) suggests that infilling of the basement trough has been influenced by sediment transport from west to northwest. A more expanded isopach map (not presented here) of the area east-southeast of Bermuda shows that the sediment accumulation in the trough is, in fact, part of the thick sediment fill at the base of the Bermuda Pedestal. This suggests, therefore, that a major portion of the sedimentary section at Site 386 consists of material shed from Bermuda and thus represents a distal extension of the deposits forming the sedimentary apron surrounding Bermuda. Prominent reflectors can be observed deep within some basement troughs (Figures 3 and 4) illustrating the ponding of older turbidite deposits.

Sediment thickness above Horizon $A^{V}$ is shown in Figure 7. Generally thicker sediments in the depressions and thinner sediments on elevated areas reflect the reworking of pelagic sediments into depressions by bottom currents and slumping.

\section{SUMMARY}

Site 386 is located in a valley with relatively thick $(1.0 \mathrm{sec})$ sediments just north of a prominent basement high. The sedimentary section is divided into two distinct units by a thin zone of highly reflective, well-stratified layers which represent turbidites The internal stratification of the lower sedimentary unit is variable and appears to consist of pelagic deposits interbedded with turbidites. The topmost unit of sediments generally is acoustically nonlaminated and appears to consist of pelagic deposits which have undergone considerable reworking by bottom currents. The sediments at Site 386 , particularly those of the thin, reflective zone and lower sedimentary unit, represent an apparent extension of the acoustically reflective sedimentary apron surrounding Bermuda. 

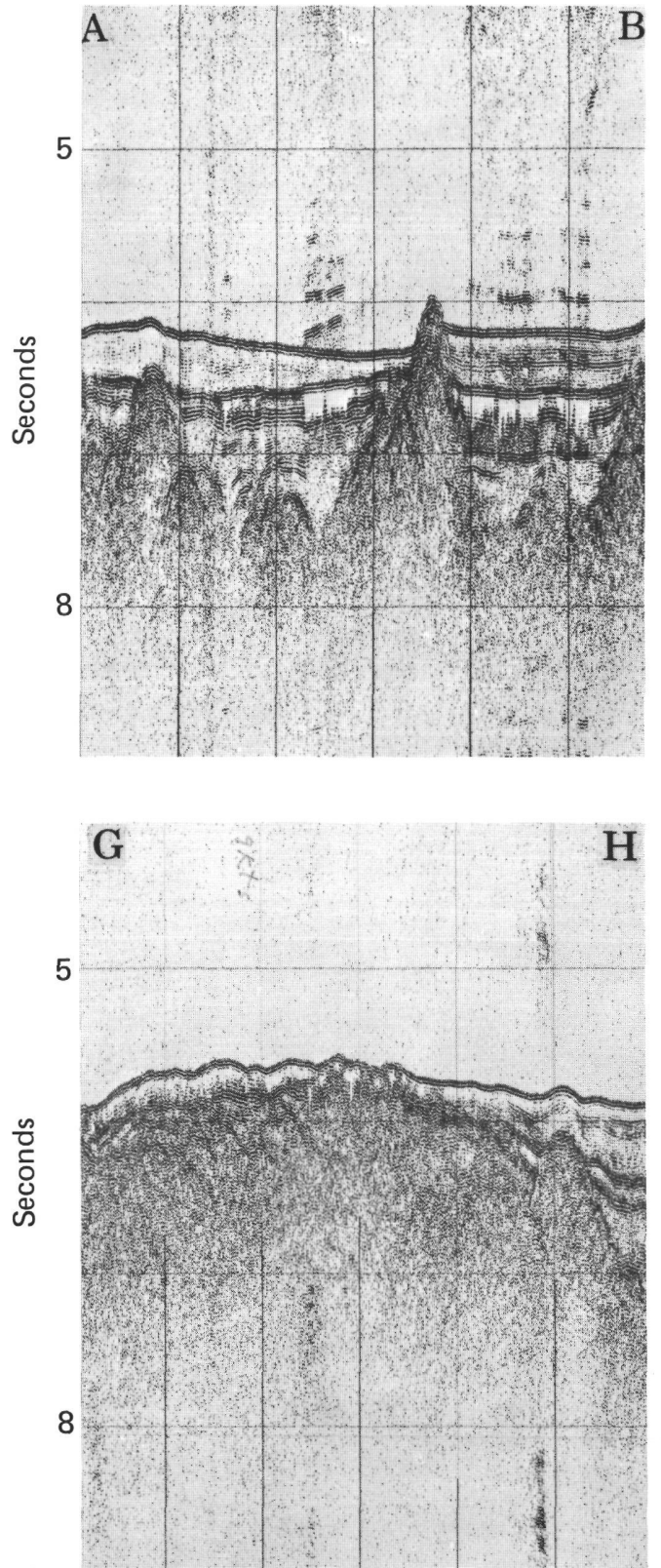
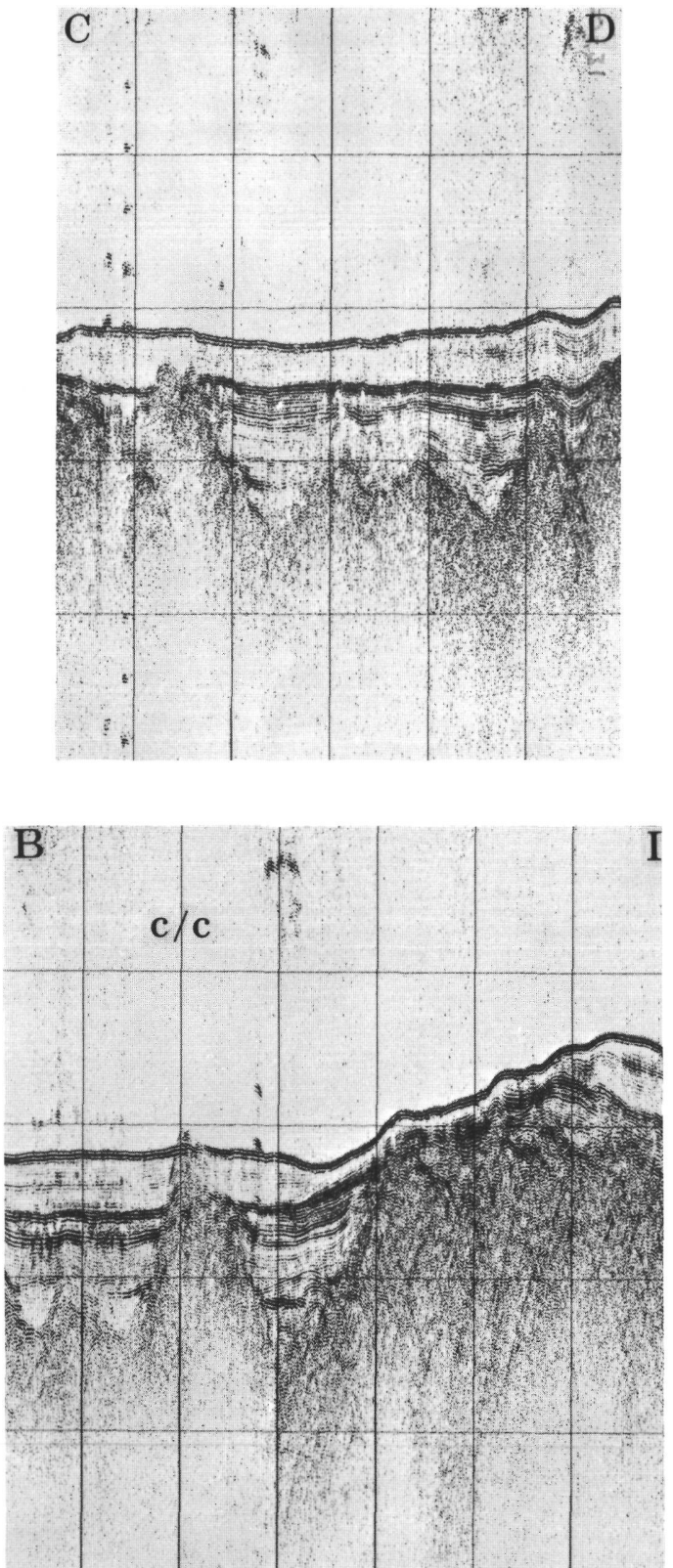

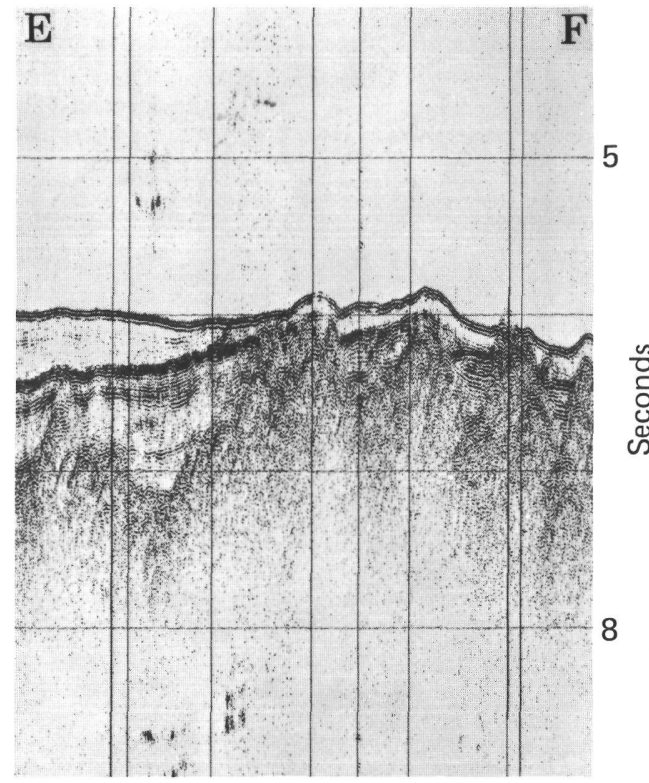

옹

\section{.}

a.
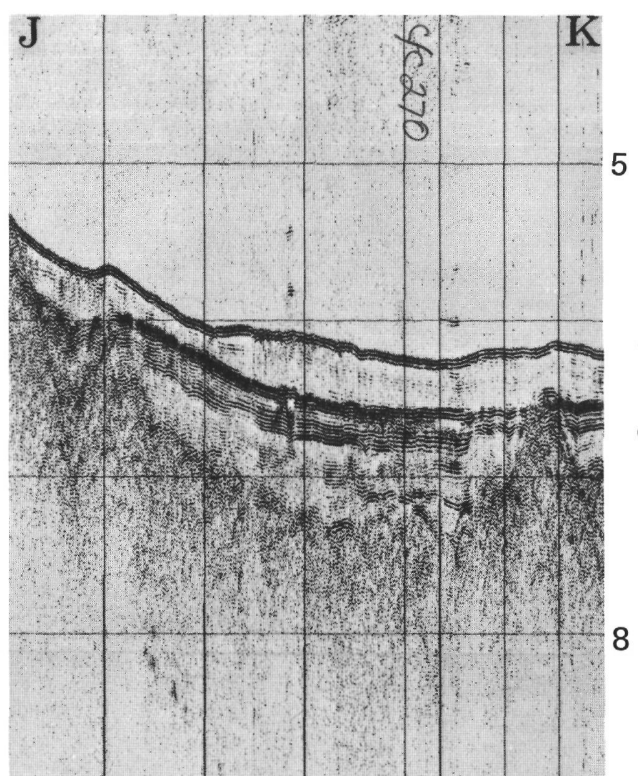

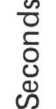



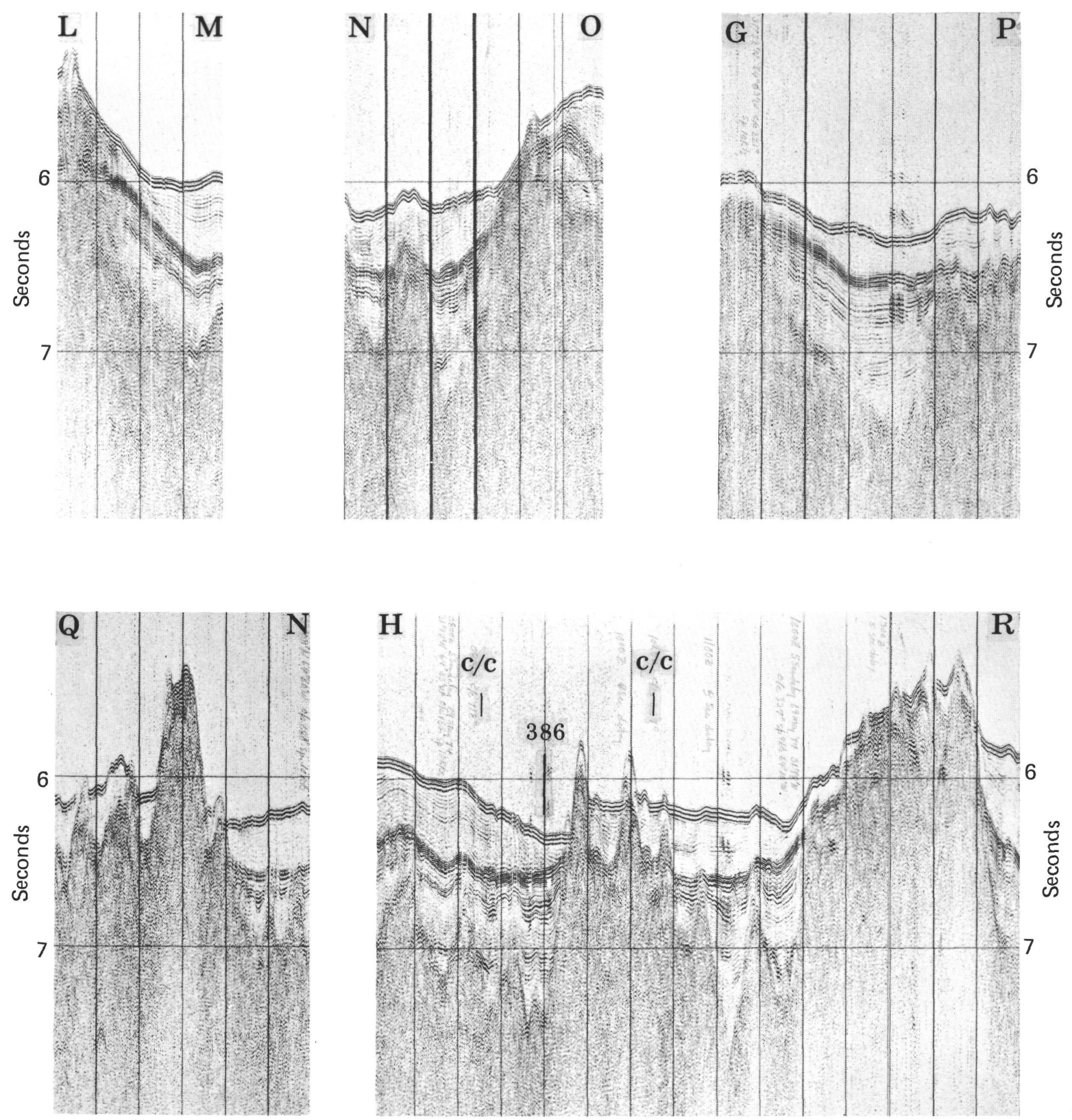

Figure 4. Seismic reflection profiles recorded by USNS Kane. Profiles are indexed on Figure 1.

\section{REFERENCES}

Heezen, B. C., Tharp, M., and Ewing, M., 1959. Floors of the oceans. I; the North Atlantic, Geol. Soc. Am., Spec. Paper 65.

Holcombe, T. L. and Heezen, B. C., 1970. Patterns of relative relief, slope, and topographic texture in the North Atlan- tic, Lamont-Doherty Geological Observatory of Columbia University, Tech. Report.

Vogt, P. R., Anderson, C. N., and Bracey, D. R., 1971. Mesozoic magnetic anomalies, sea-floor spreading and geomagnetic reversals in the southwestern North Atlantic, J. Geophys. Res., v. 76, p. 4796. 


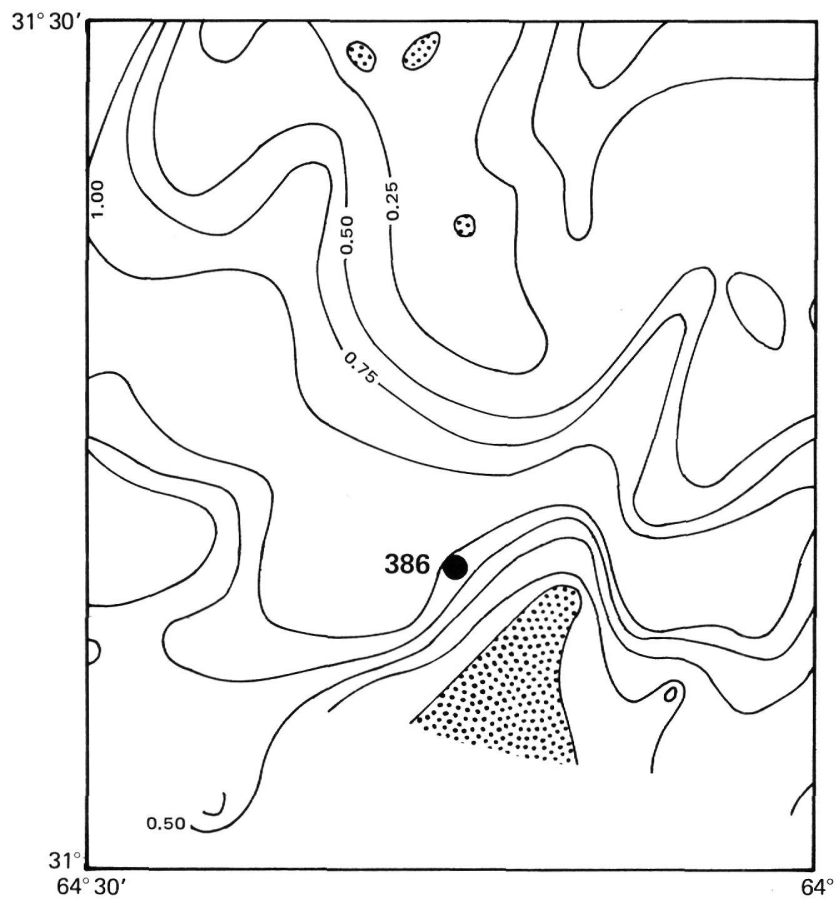

Figure 5. Isopach map showing total sediment thickness. Contours are in seconds of two-way travel time. Stippled areas mark basement outcrops. Solid circle indicates location of drilling Site 386.

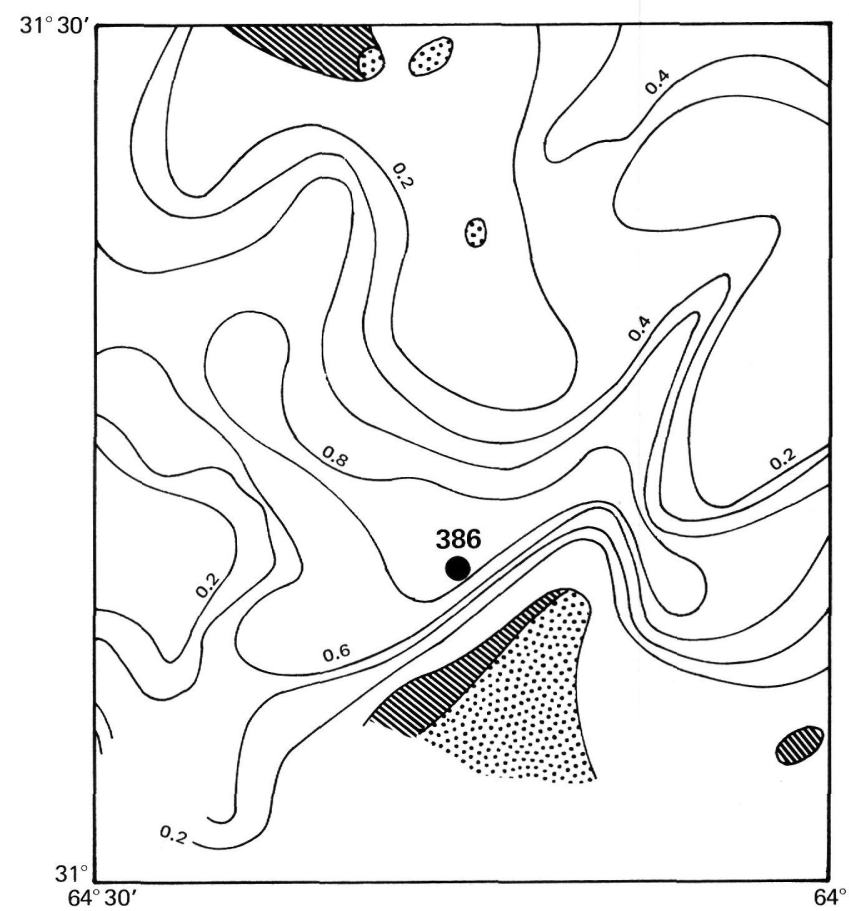

Figure 6. Isopach map showing thickness of lower sedimentary unit (below Horizon $A^{V}$ ). Contours are in seconds of two-way travel time. Stippled areas mark basement outcrops. Hatched areas indicated additional outcrop area not shown in Figure 5. Solid circle indicates location of drilling Site 386.

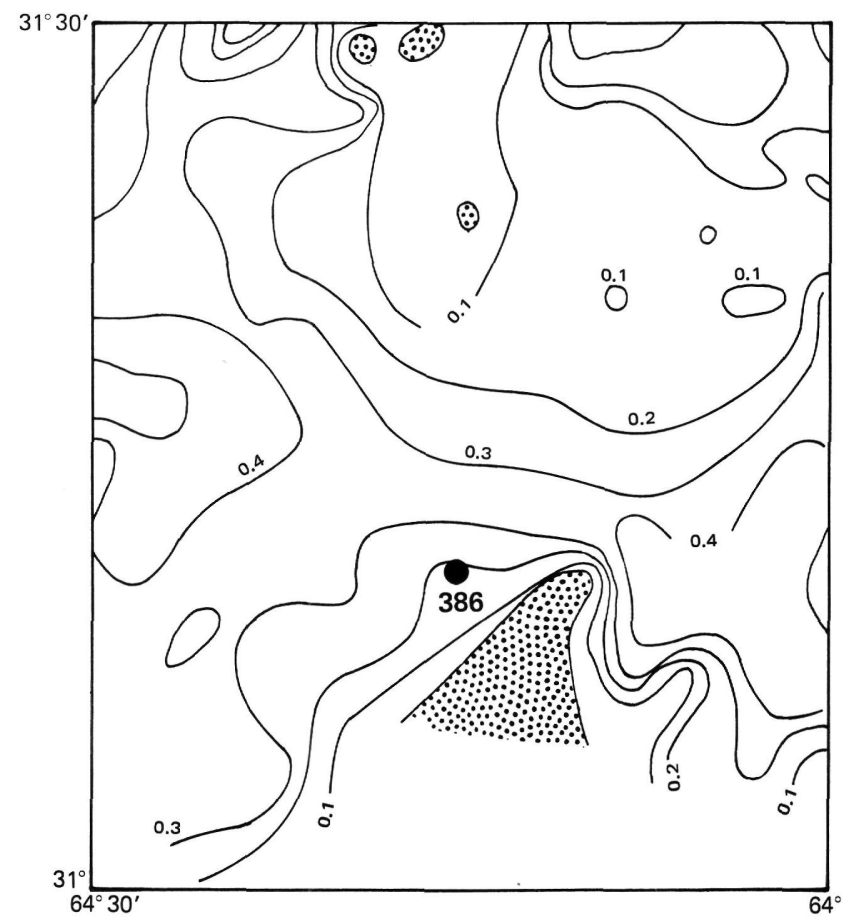

Figure 7. Isopach map showing thickness of upper sedimentary unit (above Horizon $A V$ ). Contours are in seconds of two-way travel time. Stippled areas mark basement outcrops. Solid circle indicates location of Site 386. 